\title{
METHODS FOR COMMUNICATION PROCESSES ENHANCEMENT IN THE "PROVIDER-CONSUMER (LEARNER)" SYSTEM OF EDUCATIONAL SERVICES
}

DOI: $10.36740 /$ WLek202008114

\author{
Yuriy V. Voronenko, Olesya P. Hulchiy, Iryna M. Khomenko, Nadiia M. Zakharova, Kostyantyn V. Balashov \\ SHUPYK NATIONAL MEDICAL ACADEMY OF POSTGRADUATE EDUCATION, KYIV, UKRAINE
}

\begin{abstract}
The aim: To determine learners' (doctors) needs and draw up proposals for upgrading educational communication processes in the "provider-consumer" system of educational services.

Materials and methods: The biblio-semantic, biostatistic and sociological methods were used. 754 author questionnaires were processed.

Results: The socio-professional characteristics of learning service consumers at Shupyk National Medical Academy of Postgraduate Education were analyzed as well as studied their proposals. Evaluating communication interactions in the "provider-consumer" system of educational services concerned determining the most comfortable organizational modes of education for a consumer, making a careful analysis of the learning service characteristics by "accessibility" and "effectiveness" criteria. The determination methodology and research results can be used by universities and colleges regardless of the educational program specialization.

Conclusions: Ensuring the educational communication processes effectiveness in the "provider-consumer" system of educational services is achieved by studying learners' adaptation according to such principal criteria as organizational modes of education, the learning service accessibility and effectiveness. The learning service providers adjust customer requirements to the capabilities of a particular educational institution (personnel availability, facilities and resources etc.) and so that they ensure competitiveness.
\end{abstract}

KEY WORDS: Diffusion of Innovation, Information Seeking Behavior, Communication Barriers, Continuing Education

$\overline{\text { Wiad Lek. 2020;73(8):1663-1667 }}$

\section{INTRODUCTION}

The healthcare system modern age in Ukraine and the public health philosophy introduction have turned the spotlight on using modern impact methods for public health protection. A key powerful tool, enabling to build a commitment to maintaining the health of both the population and the representatives of various industries, which effectiveness is recognized by the scientists of different schools and WHO experts, is communication [1]. Maintaining adequate comprehensive information, in particular using modern information technologies, has undoubtedly a positive impact on all communication processes. The approaches are actively implemented in the educational field of cross-sectional higher education institutions. Academic staff are organizers of effective communication in the "provider-consumer (learner)" system of educational services, in particular at doctors' continuous professional development [2].

According to WHO experts, the brisk growth and use of IT and mobile communications adjust the capabilities of the countries, differed in their economic development. Due to the reduction in the value and the simultaneous increase in the technologies accessibility, users have access to modern databases, they can use the latest achievements in science and technology, actively implement the results in various professional activities, including medicine [3].

Global informatization significantly affects the views of learning service consumers, it creates new demands on the efficiency and operability of the communication processes between learning service providers and consumers.

Today higher education institutions, including the medical ones, face new challenges as to improve the learning policy, equate its quality with the latest world standards by teaching the academic staff how to use state-of-the-art IT solutions, updating regulations, mainstreaming learning service consumers' needs [1-7].

Information technology is a fixture in modern education as it offers means for ensuring the required quality regardless of one's residence and of the higher education institution's location. Using IT has significantly broadened the array of teaching tools, enhanced the effectiveness of learning methods, and laid the groundwork for a new - distance (online) - mode of academic activities management.

Distance learning advantages are recognized in the world, this study mode involves millions of adults every year, emphasizing its unsurpassed opportunities for satisfying educational requirements during continuous professional development. Self-paced learning, the operational efficiency of a communication channel (information delivery speed), the absence of necessity to commute to class, visibility, demonstrativeness, being able to communicate with world-class specialists - all the advantages are noted by the eighteen plus consumers of educational services in most countries of the world [8-9]. 
Modern Ukrainian higher education is being transformed with the times, in compliance with the national pace of development and IT accessibility as well as subject to the educational industry growth. Distance learning is increasingly penetrating with adult education (pre-graduate, postgraduate, continuous professional development), it is used in creating authorial blended teaching and learning responding to the interdisciplinary specialists' requirements. We conceive of using distance learning or its combinations with the classical one as significantly ensuring the effective communication in the "provider-consumer" system of educational services. This is especially important under the health care reform and the public health system development.

\section{THE AIM}

The aim is to determine learners' needs and draw up proposals for upgrading educational communication processes in the "provider-consumer" system of educational services.

\section{MATERIALS AND METHODS}

The biblio-semantic, biostatistic and sociological methods as well as content analysis were used. Having analyzed the delivery of learning services in the world, in particular distance learning, we conducted our own research.

The first phase of the study was to develop the unified questionnaire which included 24 questions. The respondents were proposed several multiple choice questions (the type and length of learning, ability to operate alone, etc.), and some questions required short-answer free-text responses. We also suggested that the surveyed assess both traditional factors (tuition fee, the opportunity to see patients etc.) and the relatively new ones, such as being in a regular dialogue with the department after completion of training, publishing online information about the training course, etc.

The anonymous, voluntary questionnaires were administered to 754 doctors in order to analyze their needs and ways to enhance the communication processes efficiency. In accordance with the types of questionnaires, the learning service consumers were divided into three groups. Group A consisted of 356 people, who having found the questionnaires by themselves on the NMAPE's website or Facebook, completed it online. Group B consisted of 163 people, who were the participants of the research to practice conference at the Academy. Those respondents completed the questionnaire hard copy. Group C was comprised of 235 respondents, who answered the questionnaires arrived in the inboxes of the health care institutions.

The replies to the questionnaires were put into the common database and processed by IBM SPSS v. 23. We determined derivative values and ascertained the statistical control status of the difference between the positions of those surveyed in all the groups. The learning criteria characteristics were scored on ten-point scale, wherein those, who were given one score out of 10 , showed a minimal interest in respect to that parameter (a negative response), while those who scored 10 points, as the maximum score, took their active interest in implementing the parameter (a positive response). Average values were determined for each criterion.

\section{RESULTS AND DISCUSSION}

Using the best practices in adoption of the modern IT enables their adjustment in order to improve the quality and effectiveness of the educational process, determine the most valuable factors of confidence building in the system "provider-consumer", create institutional brand's positive features and enhance its competitive ability. To handle this tasks the research, implicating the advanced study of consumers' opinions and attitudes, was designed and implemented in Shupyk National Medical Academy of Postgraduate Education in order to take the measures intended to increase the quality of educational communication processes in the "provider-consumer" system of educational services and provide strong competitive ability of the institution.

The process of design and implementation successfully combined traditional and the latest approaches: the questionnaire was designed, consumer communication channels (hard copies, social network, official website, etc.) and result processing techniques were identified. Such an approach provided with meaningful data related to a social and professional respondent profile and their attitude regarding the organizational aspects of the educational process in the institution.

The questionnaire analysis results revealed that the mean age of respondents was 42.4 and in the groups respectively: A - 39.8 years, B -41.2 years, C - 47.2.

Within the qualification-based structure in the respondent Group A highly qualified staff and specialists (36.8\% and $36.1 \%$ respectively) were represented equally, the fact of $10.9 \%$ of the subjects having PhD may be considered as a salient feature of this group. Within the qualification-based structure of the Group B medical specialists were ahead of the ratio whereas in the Group $\mathrm{C}$ the medical specialists took the third place (14.6\%). The percentage of highly qualified doctors reached its all-time high in the Group C (56.9\%), which is illustrated on the Figure 1.

In order to identify doctors' outlooks and attitudes, when it comes to the basic organizational modes of the education process, the following versions were proposed: full-time, part-time, distance, modular and blended. The full-time mode of education implicates the presence of learners in all types of sessions (lectures, workshops, practical sessions) throughout the course. The part-time mode provides the opportunity to gain a certain content knowledge, partly hone practical skills in cooperation with an educator, but with the majority of the course to cope individually. The distance mode implicates distant support of a learner, providing him/her with corresponding learning materials, learning program, test questions, etc. The modular mode implicates full-time education on weekends and partly 


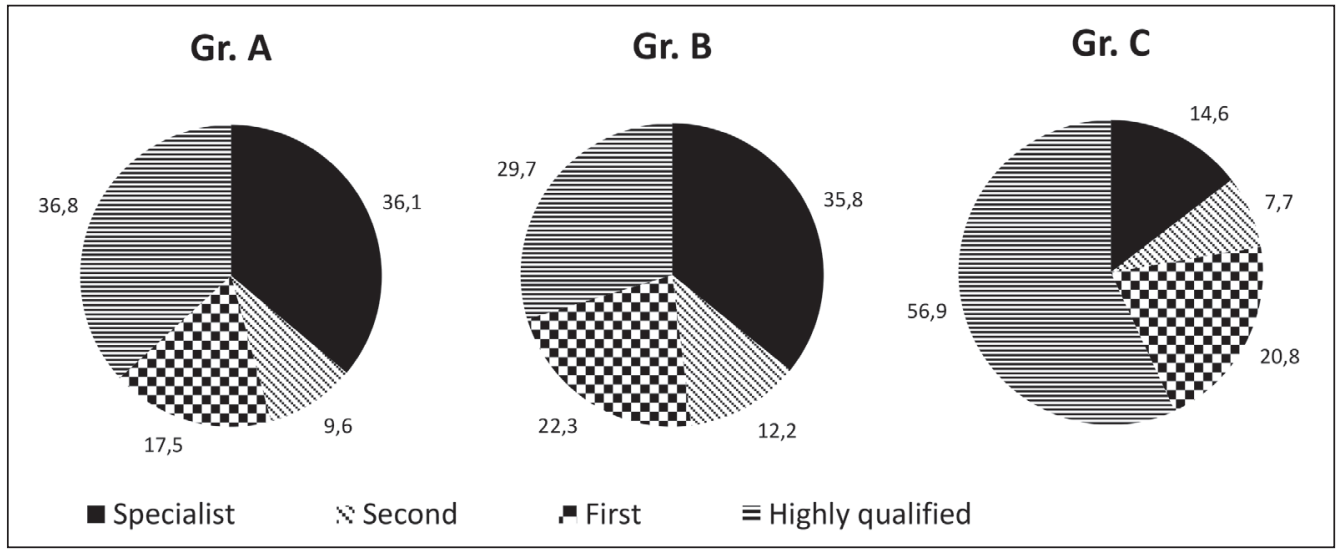

Fig. 1. Respondent distribution in three groups by qualification categories.

Table I. Accessibility and effectiveness of organizational modes of education.

\begin{tabular}{|c|c|c|c|c|c|c|c|c|c|c|}
\hline \multirow[b]{3}{*}{ Respondent group } & \multicolumn{10}{|c|}{ Modes of continuing medical education, per 100 respondents } \\
\hline & \multicolumn{2}{|c|}{ Full-time } & \multicolumn{2}{|c|}{ Distance } & \multicolumn{2}{|c|}{ Blended } & \multicolumn{2}{|c|}{ Modular } & \multicolumn{2}{|c|}{ Part-time } \\
\hline & 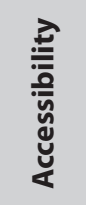 & 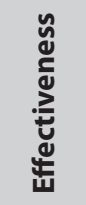 & 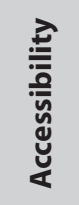 & 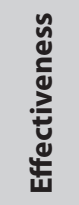 & 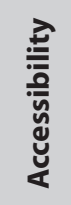 & 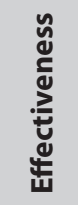 & 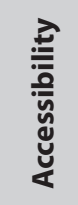 & 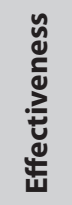 & 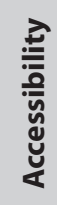 & 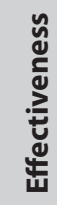 \\
\hline A & 9.6 & 25 & 43.2 & 25.3 & 36.7 & 38.9 & 7.6 & 9.7 & 2.8 & 1.1 \\
\hline B & 24.7 & 42.8 & 25.9 & 8.2 & 38.3 & 40.9 & 7.4 & 6.3 & 3.7 & 1.9 \\
\hline C & 20.7 & 44.9 & 36.7 & 20.5 & 34.6 & 29.9 & 3.4 & 2.6 & 4.6 & 2.1 \\
\hline Total & 16.3 & 35.1 & 37.4 & 20.1 & 36.4 & 36.5 & 6.3 & 6.7 & 3.6 & 1.6 \\
\hline
\end{tabular}

on Friday, during inter-modular periods a learner works distantly. The blended mode implicates full-time, part-time and distance education with unequal proportion of one or few modes at the same time.

Respondents opted for blended modes of the education process (36.5\%), distance approach comes second (28.8\%), full-time education comes third (25.7\%).

For the purpose of better understanding of respondents in their motivation we proposed them to assess the education mode and duration against two independent parameters: availability and effectiveness. By the term "education availability" we meant the following characteristics: transport and housing accessibility, education time schedules (the length of education, days of the week), as well as the ability to pay for education (financial accessibility). The term "education effectiveness" we interpreted as the learner opportunity of gaining the most profitable knowledge and improving practical skills within short time frames that will provide an expert with the opportunity of improving instantly own performance on site.

According to the survey, distance and blended modes of the educational process were selected by respondents as the most accessible - 37.4 and 36.4 answers respectively per 100 respondents (see Table1). Blended and full-time modes were considered by the respondents as the most effective education modes (36.5 and 35.1 answers respectively per 100 surveyed).
Group A and B respondents consider the blended mode of education as the most effective (38.9 and 40.9 per 100 surveyed respectively). Group C experts consider the fulltime mode as the most effective (44.9 per 100 surveyed respectively). Group A and B respondents gave weight to the distance mode of education against the criterion "accessibility" (43.2 and 36.7 per 100 surveyed respectively), group B respondents emphasized the blended mode ( 38.3 per 100 surveyed).

Such organizational modes of education as the modular and part-time gained the minimum number of votes against the criterion "accessibility" (6.3 and 3.6 per 100 surveyed respectively) and "effectiveness" (6.7 and 1.6 per 100 surveyed respectively). These modes are not typical for medical education, the majority of experts have not had a chance of experiencing the benefits of these education modes. Accordingly, principals have the opportunity to take advantages of these modes which tend to be the expectable elements of competitive edge, the way to creation of a unique combination of organizational modes.

Our survey data, regarding the expectable and effective education length of courses and sessions, will prove useful to principals, academic staff while creating or updating curricula and programs. According to the survey, it was defined that 56 day sessions are considered by respondents as the optimum education length both against the criteria "accessibility" and "effectiveness" (34.8 and 35.3 per 100 


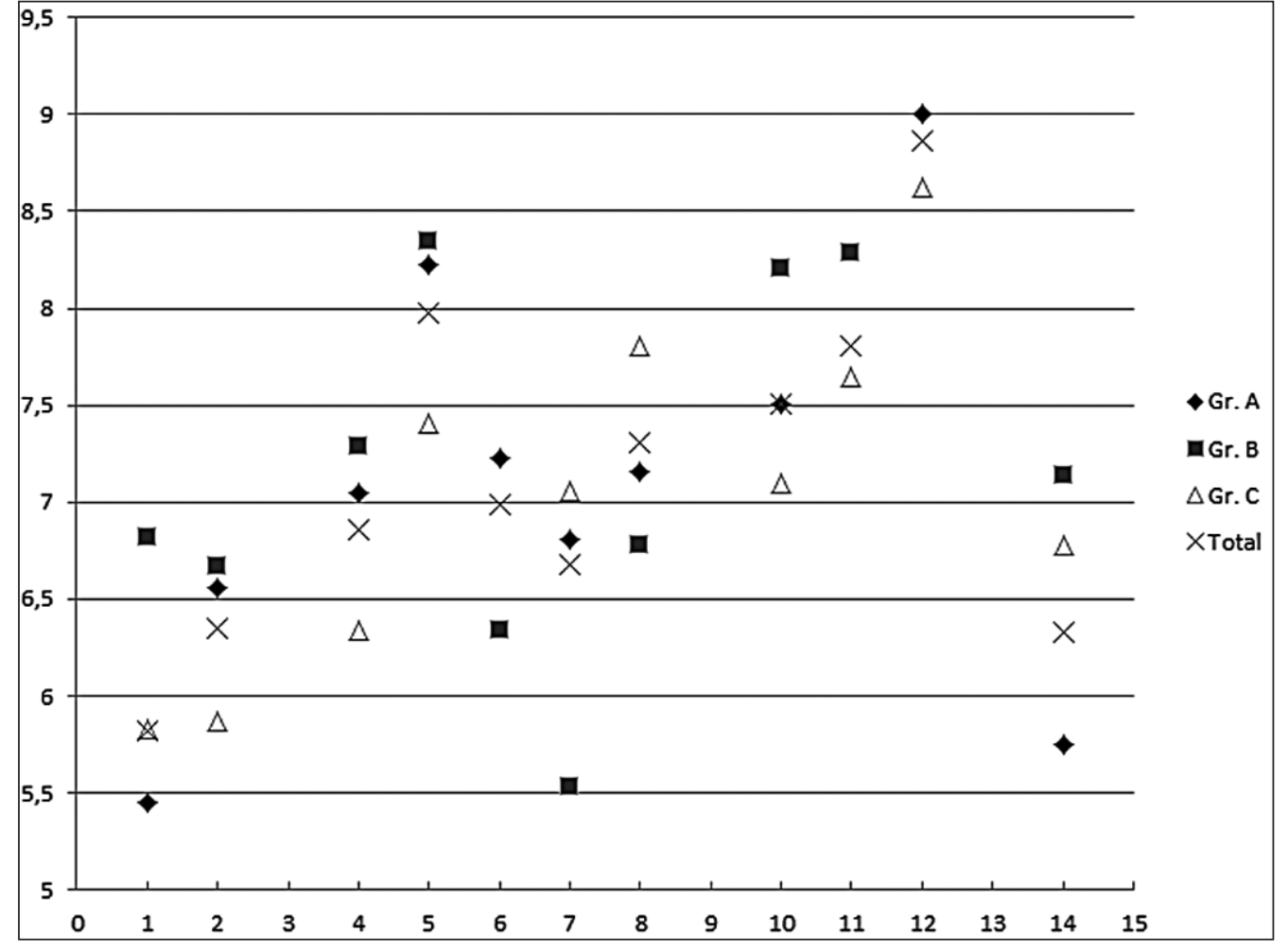

Fig. 2. Respondents'attitude to separate criteria for education services, average points.

* - X-axis labels:

1 - previous teaching experience at this department;

2 - colleagues' suggestions;

3 - territorial accessibility;

4- feedback on the session;

5 - publicly available information about the objective and enrollment; 6-workload;

7 - necessity of relocation

to another city;

8 - living environment;

9 - education cost;

10 - engagement of

foreign educators;

11 - interaction with educators after graduation;

12 - materials available for distance education; 13 - opportunity to treat patients; 14 - doctorate degree holders among lecturers; 15 - public figures among lecturers. surveyed respectively). Two-three-day sessions are also considered accessible (24.9 per 100 surveyed), while against the criterion "effectiveness" - sessions lasting over 15 days (22.4 per 100 surveyed).

The in-depth analysis of the significance of certain criteria (ANOVA with post hoc Scheffe and Tamhane's tests were used), has been demonstrated, that let learners consider education services as "accessible". The principal criterion for session selection in connection with the qualities of education accessibility, in respondents' opinion, is its cost. This quality of education accessibility held $8.2 \pm 0.2$ points avg., statistical dispersion of respondents' attitudes in 3 groups has not been calculated (8.1 points in Group A; 7.9 points in Group B and 8.3 in Group C), that indicates the significance of this quality for all the respondents (see Figure 2). Consequently, a cost or other additional organizational aspects, which may be related, should be considered as one of the crucial criteria that develop competitive ability of an academic institution and/or separate education products.

The existence of publicly available, complete and comprehensible information concerning the education offer, on the academic website, Facebook page or other resources in particular, was ranked at $8.0 \pm 0.2$ points, on the average. Group A and B respondents, comparing to Group C, considered this criterion as statistically more significant $(\mathrm{p}<0.01$ and $\mathrm{p}<0.05$ respectively). Consequently, availability of information about a session (education product): its objective, content of theoretical aspects and/or practical skills, etc. impacts markedly the opportunity to attract consumers of education services.

The third factor mentioned by respondents - territorial accessibility. The mean score of this characteristic was
$7.7 \pm 0.2$ points, statistically significant dispersion among the subjects of three groups have not been calculated that indicates the importance of this characteristic for each respondent group.

This is the first study concerning the socio-professional characteristics of learning service consumers at Shupyk National Medical Academy of Postgraduate Education. It is worth mentioning that resulting from the analysis of respondent feedbacks the following three characteristics got the highest points: distance learning package (statistically significant characteristic for Group A comparing to Group C, $\mathrm{p}<0.05$ ), opportunity for being in touch with educators after completing a session (statistically significant characteristic for Group B comparing to Group C, $\mathrm{p}<0.05)$ and opportunity to hone practical skills in realistic environment including treating patients $(8.9 \pm 0.2$ points, $7.8 \pm 0.3$ points and $7.7 \pm 0.2$ respectively). The statistically significant dispersion between respondent groups against the last characteristic have not been identified. We consider expedient the use of these organizational elements while designing and implementing education services in order to enhance competitive ability of an institution, facilitating promotion of certain education products and/or a certain lecturer - expert in the field. Due to the rapid technological advances and intensive informatization, the higher education institutions, including the medical ones, are faced with the tasks of upgrading educational communication processes in the "provider-consumer (learner)" system of educational services. The general approach to studying and describing the profile of learn service consumers, proposed in the article, can be of utility to any higher education institution, both in Ukraine and abroad. 


\section{CONCLUSIONS}

1. The authors' approach to studying the preferences and positions of learn service consumers by creating an appropriate questionnaire, using various communication channels (a hard copy, e-mail, the global social network, the official website of the institution) make it possible to study various consumers' profiles and, accordingly, determine desirable organizational modes of education, especially given the "accessibility" and "effectiveness" criteria, which are considerable factors that influence the competitiveness of the institution and its educational products.

2. Having analyzed the respondents' responses we found the full-time, online and blended learning modes to be the most expected organizational modes of education. The optimal learning course averages out to 5-6 days, in the estimation of most health care professionals. Such characteristics of educational services as accessibility and transparency are assumed to be the key ones. The future close communication with academic and scientific community on completing the training course, the educational package provision and the expertise acquisition focus build crucial requirements to the enhancement of educational services.

\section{REFERENCES}

1. Voronenko Y., Hulchiy 0., Zakharova N. et al. Komunikatsiyna kompetentsiya yak skladova kompleksnoho navchannya fakhivtsiv hromads'koho zdorov"ya. Ukrayina. Zdorov"ya natsiyi. 2017;3 (44):309-310. (In Ukrainian).

2. Voronenko Y., Mintser 0., Krasnov V. Orhanizatsiia bezperervnoho profesiinoho rozvytku vykladachiv u systemi medychnoi osvity (analitychnyi ohliad ta propozytsii). Medychna osvita. 2012; 4:6-17. (In Ukrainian).

3. Global difusion of eHealth: making universal health coverage achievable. Report of the third global survey on eHealth. Geneva:World Health Organization; 2016, p. 93-94.

4. Hulchiy 0. , Zakharova N. Metodolohichni aspekty rozrobky navchalnykh prohram dlia pisliadyplomnoi osvity v okhoroni zdorovia. Naukovyi visnyk Natsionalnoho medychnoho universytetu imeni 0.0 . Bohomoltsia. 2010;1:197-201. (In Ukrainian).

5. Utengen A., Rouholiman D., Gamble J.G. et al. Patient Participation at Health Care Conferences: Engaged Patients Increase Information Flow, Expand Propagation, and Deepen Engagement in the Conversation of Tweets Compared to Physicians or Researchers. J Med Internet Res. 2017;19 (8):219-222. doi: 10.2196/jmir.8049
6. Pohoriliak R., Hulchiy 0 . Vyvchennia problemy pidhotovky suchasnykh kerivnykh kadriv okhorony zdorovia v Ukraini. Kyiv: Ukraina. Zdorovia natsii. 2015;4:76-80. (In Ukrainian).

7. Slater M. Choosing audience segmentation strategies and methods for health communication. In: Maibach E, Parrott RL, eds. Designing health messages: approaches from communication theory and public health practice. Thousand Oaks,CA:SAGE Publications;1995, p. 199-200.

8. Allen I.E., Seaman J. Going the Distance: Online Education in the United States. Babson Survey Research Group. 2011, p.15-16.

9. Moore M.G., Kearsley G. Distance Education: a systems view of online learning,3rd ed. Belmont, CA:Wadsworth Cengage Learning;2012, p.5-8.

\section{ORCID and contributionship:}

Yuriy V. Voronenko: 0000-0002-4852-3324 A,E,F

Olesya P. Hulchiy: 0000-0001-8283-8672 A,C,E

Iryna M. Khomenko: 0000-0002-8412-6393 ${ }^{\mathrm{E}}$

Nadiia M. Zakharova: 0000-0002-6530-6217 C,D,E

Kostyantyn V. Balashov: 0000-0002-7820-4527 B,C,D

\section{Conflict of interest:}

The Authors declare no conflict of interest.

\section{CORRESPONDING AUTHOR Kostyantyn V. Balashov \\ Shupyk National Medical Academy \\ of Postgraduate Education 9 Dorohozhytska str., 04112 Kyiv, Ukraine \\ tel: +380668994380 \\ e-mail: kostyantyn.balashov@gmail.com}

Received: 25.01 .2020

Accepted: 08.06 .2020

\footnotetext{
A - Work concept and design, B - Data collection and analysis, C - Responsibility for statistical analysis,
} D-Writing the article, $\mathbf{E}$-Critical review, $\mathbf{F}$ - Final approval of the article 